\title{
ANALYSIS OF PHYSICAL FITNESS ON STUDENT LEARNING OUTCOMES
}

\author{
*Wenda Wulan Agustin, Hartati, Silvi Aryanti \\ Correspondence: Universitas Sriwijaya, Palembang, Indonesia \\ Email: hartati@ fkip.unsri.ac.id
}

\begin{abstract}
This study aimed to find out about physical fitness, learning outcomes, and the relationship of physical fitness for third-semester Physical education and Health students at FKIP Sriwijaya University. The type of research used is descriptive and with a correlation design. The population of this research is the thirdsemester students. The sample in this study was 67 students of the third semester. The instruments used the Harvard step test and secondary data from the cumulative grade point index (IPK) learning outcomes. Technique for analysis data was processed by percentage and used computer assistance through the SPSS 22 program. Based on the analysis of the portion of data obtained, the result of student physical fitness received a rate of $81 \%$, amounting to 54 students with excellent categories, $15 \%$ amounting to 10 students in suitable classes, and 4\% amounting to a student with enough types. Learning outcomes (IPK) of students obtained a percentage of $73 \%$, amounting to 49 students with praise and $27 \%$ of 18 students with satisfying predicates. The result of the correlation test data analysis technique $r=0,000$ less than 0,05 indicates a significant relationship between physical fitness and student learning outcomes. The development of the interpretation of the coefficient is $=0,598$, which includes a moderate level of connection and contributes $34,8 \%$. The implication of this research is that good physical fitness will affect the achievement of good learning outcomes.
\end{abstract}

\section{Keywords: Learning Outcomes, Physical Fitness, Student}

\section{Introductions}

Physical fitness is a person's ability to carry out physical activities and other activities and as a support in daily activities. According to Santoso (2016), physical fitness is the ability of a person's body to carry out daily activities or work without feeling fatigued. The level of physical fitness that a person has will always describe a person's behavior in his life and depends on a person's intelligence in maintaining and maintaining physical fitness.

The Physical Education and Health study program is within the Teacher Training and Education Faculty (FKIP) Sriwijaya University. Bachelor of physical education and health is one of the government's efforts to realize increased physical fitness and intelligence in students. Students of physical education and health have more physical activity than students of other study 
programs. The hallmark of the physical education and health study program is that the material provided includes theory and field practice (Sumarsono 2017).

Students who have good physical fitness will have the power of concentration, endurance, and energy in carrying out their learning activities. As said by Rismayanthi (2012) that physical fitness possessed by students is expected to support student achievement and learning outcomes and especially achievements in the field of sports according to the sport they are engaged in. Physical fitness functions are many, not only for athletes but for anyone who wants to have and maintain physical fitness. Physical fitness serves to carry out work abilities or other activities to complete tasks well without experiencing severe fatigue and achieve good performance results with good physical fitness (Soraya, Sugiharto, and Defliyanto 2019).

Good physical fitness will result in good physical abilities as well; students who are always active in sports or physical activity, then their physical fitness will be good and can affect their learning outcomes than students who have low physical fitness. Based on the results of interviews by telephone and messenger via WhatsApp, several students found differences in factors, namely food, rest, activity, and exercise factors. Face-to-face learning is no longer carried out due to the coronavirus (covid-19) pandemic. Lectures are currently conducted online, limiting students to exercise and movement. As stated by Fajar \& Iswahyudi (2018), the main cause of the decline in student physical fitness is due to their lack of activity in moving.

The demands of students from mastering the ability of three domains, namely cognitive, psychomotor, and affective, are also more basic than students who are in school, and students are required to have good learning outcomes. According to Zahri et al. (2017) explaining that the learning outcomes are to find out the extent to which students understand the lessons that have been given. Student learning outcomes can be seen through tests (numbers) given by lecturers who support the course as a result of their efforts in learning in the form of a cumulative achevementindex (GPA) (Fitri 2019)! The results of the GPA on students reflect the achievement index that he pioneered from the beginning of entering college until a certain semester. GPA results function in determining the taking of credits or study load for the next semester. According to Sriwijaya \& Sriwijaya, (2020) taking the study load or credits for the next semester refers to the achievement index (IP), namely IP > $3.00=$ maximum 24 credits, IP $2.50-$ $2.99=$ maximum 21 credits, IP $1.50-1.99=$ maximum 15 credits, and IP $<1.20=$ maximum of 12 credits. Learning outcomes, namely GPA, is one of the determinants of students to graduate and get a graduation predicate consisting of praise (cum laude), very satisfying, and satisfying.

Based on this, students should have good physical fitness because it can affect their learning outcomes.

Physical education and health are for muscle building and can also improve intelligence and a good personality. Based on the results of research conducted by 
Riyanto (2020), it was found that physical fitness can affect learning outcomes in students.

Based on the background of the problem, the formulation of the situation in this study is how physical fitness, learning outcomes, and the relationship of physical fitness to students' learning outcomes of physical education and health in the third semester of FKIP Sriwijaya University. This study aims to determine how physical fitness, learning outcomes, and the relationship to the learning outcomes of third-semester physical education and health students at FKIP Sriwijaya University.

\section{Method}

This study uses a descriptive type of research, with the research method used is a survey method and uses a correlation design. Correlation is done to see the relationship between two variables (Siyoto and Sodik 2015). The population and the sample of this study were all students of physical education and health in the third semester of FKIP Sriwijaya University. The instruments in data collection used by each of these variables are, for physical fitness the device is a Harvard step test (Saputra, Sugiyanto, and Defliyanto 2019), while for learning outcomes using secondary data for third-semester students' GPA is by students fill out the google form that has been provided. The analytical technique used in this research is to use the percentage and product-moment correlation with the help of the SPSS 22 program.

\section{Discussion}

This study has two variables. Namely, the independent variable is physical fitness, and the dependent variable is learning outcomes. Based on the results of the physical fitness test $(X)$ using the up and down bench test (Harvard step test), it is known that the results of the third-semester students' physical fitness scores can be seen in the following table:

Journal Physical Education, Health and Recreation

Table 1. Analysis of Student Physical Fitness Test

\begin{tabular}{ccccc} 
No & Value & Category & Frequency & Percentage \\
\hline 1 & $90>90$ & Very well & 54 & $81 \%$ \\
\hline 2 & $80-89$ & Well & 10 & $15 \%$ \\
\hline 3 & $65-79$ & Enough & 3 & $4 \%$ \\
\hline 4 & $56-64$ & Currently & 0 & $0 \%$ \\
\hline 5 & $<55$ & Bad & 0 & $0 \%$ \\
\hline & Total & & $\mathbf{6 7}$ & $\mathbf{1 0 0 \%}$ \\
\hline
\end{tabular}


From the table above, it can be concluded that the results of the physical fitness test scores of third-semester physical education and health students of FKIP University, namely 54 students have physical fitness which is in the very good category $(81 \%)$, ten students are in a good category $(15 \%)$, three students are in the moderate category. (4\%), and there are no third-semester students who have physical fitness in the moderate and poor categories $(0 \%)$.

Physical fitness is support in students' daily activities; it is known that in physical education and health students in lectures, the learning material includes theory and practice. One way to get good physical fitness is by exercising. According to Alamsyah, Hestiningsih, and Saraswati (2017), exercise can be useful to prevent the occurrence of stressors so that they are not more harmful to body health. Having and maintaining good physical fitness must pay attention to what components of physical fitness need to be improved and maintained. Physical fitness components are divided into two, namely those related to health and skills. Physical fitness components related to health, namely cardiovascular endurance, muscle strength, flexibility, and body composition, and components of physical fitness related to skills, namely dexterity, agility, balance, coordination, muscle explosive power, reaction, and speed (Palar, Wongkar, and Ticoalu 2015).

Not only physical fitness components that need to be considered to have and maintain physical fitness, namely knowing what factors can affect students' physical fitness. According to Arifin (2018), there are two factors to influence physical fitness, namely internal factors, and external factors. Internal factors are factors that exist within themselves, such as age, genetics, and gender. External factors are factors from outside, such as activities, lifestyle, food (nutrition), and exercise. Physical fitness has many benefits for anyone, not only athletes, one of which is to avoid disease. The benefits of physical fitness, according to Carsiwan and Sandrawaty (2016), are to prevent various diseases such as heart, blood vessels, obesity, and lungs.

Based on the learning outcomes obtained, it is known that the learning outcomes or cumulative aehievernent index"(GPA) of third-semester students can be seen as shown in the following table:

Table. 2 Analysis of Learning Outcomes

\begin{tabular}{rcccc} 
No & GPA & Predicate & Frequency & Percentage \\
\hline 1 & $3,51-4,00$ & Pujian & 49 & $73 \%$ \\
\hline 2 & $3,01-3,50$ & Sangat Memuaska & 18 & $27 \%$ \\
\hline 3 & $2,76-3,00$ & Memuaskan & 0 & $0 \%$ \\
\hline & & $\mathbf{6 7}$ & $\mathbf{1 0 0 \%}$ \\
\hline
\end{tabular}

From the table above, it can be concluded that the learning outcomes of students in physical education and health in the third semester of FKIP Sriwijaya 
University, namely 49 students received learning outcomes (GPA) with honors (73\%), 18 students entered the predicate very satisfactory $(27 \%)$, and there were no semester students. III gets a satisfactory predicate $(0 \%)$. Learning outcomes are assessment processes that are given by lecturers referring to cognitive, affective, and psychomotor aspects. The GPA results obtained by the third-semester students are the results of all the courses that have been taken and the achievement index (IP). Therefore, students are required to have intelligence and good learning outcomes from the beginning of the semester to graduation. Learning outcomes can be influenced by factors that exist within oneself and from outside. According to Kurniawan, Wiharna, and Permana (2018), there are two factors, namely internal factors that exist in oneself such as physiological, psychological, intelligence, and external factors, namely factors originating from outside such as length of study, joining organizations, pocket money, and internet use.

Based on the results of the data above, then correlation analysis to determine whether there is a relationship and how big the relationship between these two variables. The measure used to determine the degree of closeness is used with the Pearson Product Moment using the SPSS 22 computer program. The correlation between physical fitness and learning outcomes of $\mathrm{rxy}=0.598$ is classified as a moderate relationship. Furthermore, to determine the significance of $\mathrm{X}$ to $\mathrm{Y}$ using $r$ table, in the following table:

Table. 3 Analysis of the Relationship of Physical Fitness to Student Learning Outcomes

\begin{tabular}{cc|cccc}
\hline Correlation & $\mathbf{r}$ (Sig) & $\mathbf{R}_{\text {count }}$ & $\mathbf{R}_{\text {table }}$ & $\mathbf{R}^{\mathbf{2}}$ & Information \\
\hline $\mathrm{X}$ and Y & 0,000 & 0,598 & 0,244 & 0,348 & Signifikan \\
\hline & & & & &
\end{tabular}

Based on the value of $r=0.000$, which is less than 0.05 , it means that there is a relationship between the two variables. Test criteria: If rcount $>$ rtable or $0,598>0,244$, then there is a significant relationship between physical fitness and learning outcomes Pof fthirdasemesterastudents lofaphysieal cedueationaand health, FKIP Sriwijaya University with a moderate level, and contributes $34.8 \%$.

Based on the results of data analysis that has been carried out on the variables of physical fitness and learning outcomes, it can be summarized through discussions which include student physical fitness in general very good, student learning outcomes, in general, get predicate with praise (cumlaude), and there is a significant relationship between physical fitness and results - student learning at a moderate level and contributed $34.8 \%$. The results of this study are the same as those found by Hartati et al. (2020), which states that physical fitness can affect the cumulative achievement index (GPA) in students.

The current COVID-19 pandemic period does not dampen the enthusiasm of third-semester students to exercise and maintain their physical fitness. Physical fitness is very important for students of the Penjaskesrek study program because physical fitness is the ability of students to be able to carry out their duties with enthusiasm, without excessive fatigue, and can increase intelligence or intelligence (Latar, T, and Tomasoa 2020). Physical fitness can be obtained by 
exercising or physical activity. Exercising requires training. Exercises that are needed and considered are cardiorespiratory, endurance, and flexibility exercises (Prativi, Soegiyanto, and Sutardji 2013). Exercise should be done every day and continuously because by exercising or physical activity the body will become healthy and fit.

Learning outcomes can serve to determine the study load to be taken in the next semester, graduation criteria, and can be used for work. Students who will take the undergraduate level civil service test have special requirements, namely a minimum graduate GPA of 3.00 because it is hoped that students who will graduate can get good GPA results according to the standards for determining civil servants. Based on this study, physical fitness is very important for students, especially students of physical education and health semester III FKIP Sriwijaya University who want to have and maintain physical fitness, one of which can enhance learning outcomes, willingness to learn, and enhance the ability to learn.

\section{Conclusion}

Based on the results of data, hypothesis testing, and discussion, it can be concluded that physical education and health students in the third semester of FKIP Sriwijaya University, in general, have very good physical fitness, get learning outcomes with honors, and there is a significant relationship between physical fitness and student learning outcomes.

\section{References}

Alamsyah, Devy Amelia Nurul, Retno Hestiningsih, and Lintang Dian Saraswati. 2017. "Faktor-Faktor Yang Berhubungan Dengan Kebugaran Jasmani Pada Remaja Siswa Kelas Xi Smk Negeri 11 Semarang." Jurnal Kesehatan Masyarakat (e-Journal) 5(3):77-86.

Arifin, Zainul. 2018. "Pengaruh Latihan Senam Kebugaran Jasmani (Skj) Terhadaptingkat Kebugaran Siswa Kelas V Di Min Donomulyo Kabupaten MaFang!" GourndisAE-MEDARRIS $\Phi(1): 22$-29.th and Recreation

Carsiwan, and Mira Sandrawaty. 2016. "Pengaruh Pembelajaran Permainan Hoki Terhadap Kebugaran Jasmani Dan Kepercayaan Diri Siswa Di Sma Negeri 26 Garut." Jurnal Terapan Ilmu Keolahragaan 1(2):59-63.

Fajar, Muhammad Kharis, and Nanda Iswahyudi. 2018. "Pengaruh Latihan Plyometric Terhadap Kebugaran Jasmani Mahasiswa Universitas Kahuripan Kediri 2017/2018.” Kolutus: Jurnal Pendidikan Kahuripan 1(2):120-39.

Fitri, Mellyna Eka Yan. 2019. "PENGGUNAAN MEDIA SOSIAL." Benefita 4(3):507-25.

Hartati, Iyakrus, Desriana, and Lordinio A. Vergara. 2020. "Physical Fitness Level Vs Comulative Achievement Index." Sys Rev Pharm 11(12):2019-23.

Kurniawan, Budi, Ono Wiharna, and Tatang Permana. 2018. "Studi Analisis Faktor-Faktor Yang Mempengaruhi Hasil Belajar Pada Mata Pelajaran Teknik Listrik Dasar Otomotif." Journal of Mechanical Engineering Education 4(2): 156-62. 
Latar, Idris Moh, Josiano J. T, and Tomasoa. 2020. "Pengaruh Tingkat Kebugaran Jasmani Terhadap Hasil Belajar Bola Basket Mahasiswa Program Studi Penjaskesrek Angkatan 2018." Jurnal Ilmiah Wahana Pendidikan 6(3):295307.

Palar, Chrisly M., Djon Wongkar, and Shane H. R. Ticoalu. 2015. "Manfaat Latihan Olahraga Aerobik Terhadap Kebugaran Fisik Manusia." Jurnal EBiomedik 3(1):316-21.

Prativi, Gilang Okta, Soegiyanto, and Sutardji. 2013. "Pengaruh Aktivitas Olahraga Terhadap Kebugaran Jasmani." Journal of Sport Sciences and Fitness 2(3):32-36.

Rismayanthi, Cerika. 2012. "Hubungan Status Gizi Dan Tingkat Kebugaran Jasmani Terhadap Prestasi Hasil Belajar Mahasiswa." Jurnal Kependidikan: Penelitian Inovasi Pembelajaran 42(1):29-38.

Riyanto, Pulung. 2020. "Kontribusi Aktifitas Fisik, Kebugaran Jasmani Terhadap Hasil Belajar Pendidikan Jasmani Contribution of Physical Activity, Physical Fitness to Learning Outcomes of Physical Education." Journal of Physical and Outdoor Education 2(1):117-26.

Santoso, Danang A. R. I. 2016. "Analisis Tingkat Kebugaran Jasmani Atlet Bolavoli Putri Universitas Pgri Banyuwangi.” Kejora 1(1):37ł46.

Saputra, Suwandi, Sugiyanto Sugiyanto, and Defliyanto Defliyanto. 2019. "Studi Kebugaran Jasmani Menggunakan Metode Harvard Step Tes Pada Mahasiswa Penjas Semester Vi Universitas Bengkulu Tahun Akademik 2018-2019." Kinestetik 3(2):193-97.

Siyoto, Sandu, and Ali Sodik. 2015. Dasar Metodologi Penelitian. edited by Ayup. Yogyakarta: Juni 2015.

Soraya, Intan, Tono Sugiharto, and Defliyanto. 2019. "PENGARUH LATIHAN SKJ 2018 TERHADAP PENINGKATAN KEBUGARAN JASMANI MAHASISWA PUTRI PENJAS UNIB." Kinestetik 3(2):249-55.

Sriwijaya, Universitas, and Rektor Universitas Sriwijaya. 2020. BUKU PEDOMAN AKADEMIK DAĀKEMAHASTSWAANCTAAUN AK 2020/2021. Indralaya.

Sumarsono, Adi. 2017. "Perbedaan Kebugaran Kardioresperasi Mahasiswa Jurusan Penjaskesrek Tahun 2013 Dan Tahun 2016 Universitas Musamus." Magistra 226(1):135-50.

Zahri, Triave Nuzila, A. Muri Yusuf, and Neviyarni S. 2017. "Hubungan Gaya Belajar Dan Keterampilan Belajar Dengan Hasil Belajar Mahasiswa Serta Implikasinya Dalam Pelayanan Bimbingan Dan Konseling Di Fakultas Ilmu Pendidikan Universitas Negeri Padang." Konselor 6(1):18-23. 